\title{
PERBEDAAN ASUPAN ENERGI, ZAT GIZI MAKRO, AKTIVITAS FISIK, DAN STATUS GIZI ANAK SEKOLAH DASAR
}

\author{
Priska Tamara Taradipa, Ani Margawati", Rachma Purwanti, Aryu Candra \\ Departemen Ilmu Gizi, Fakultas Kedokteran, Universitas Diponegoro. Jl. Prof. Sudarto SH, Tembalang, Semarang, Jawa Tengah 50275, Indonesia \\ "Penulis Penanggungjawab: E-mail: animargawati@gmail.com
}

\begin{abstract}
Background: Some schools apply different learning process and policies regarding physical activity and food service. Nutritional status can be influenced by food intake and physical activity. The aim of this study was to analyze differences in energy intake, macronutrients, physical activity and nutritional status of primary school children in SD Negeri Lerep 05 and SD Alam Ungaran.

Methods: A cross sectional study design with 44 subjects counted by sample size for a hypothesis test for two independent population proportions. Subjects were student at SDN Lerep 05 and SD Alam Ungaran. Energy and macronutrients intake obtained through food records ( 3 days: 2 weekdays, 1 weekend) and analyzed using Nutrisurvey. Physical activity was measured using the Physical Activity Questionnaire for Children (PAQ-C). Nutritional status based on Body Mass Index by Age (BMI / U). Data were analyzed by Chi-Square and Mann-Whitney tests.

Results: Most of the subjects from SDN Lerep 05 had less energy intake while at school (90.9\%), moderate physical activity level (63.6\%), excess nutritional status BMI / U> 1 SD (45.5\%). Most of the subjects from SD Alam Ungaran had adequate energy intake while at school (40.9\%) moderate physical activity level (45.5\%), normal nutritional status (68.2\%). There were significant differences between energy $(p=0.001)$, protein $(p=0.001)$, carbohydrate $(p=0.013)$ in subjects while at school, total protein in subjects $(p=0.002)$, physical activity in subjects while at home $(p=0.021)$. There were no differences between total energy intake in subjects $(p=0.221)$, physical activity in subjects while at school $(p=0.602)$, nutritional status in subjects $(p=0.167)$.

Conclusions: There were significant differences between energy, protein and carbohydrate intake in subjects while at school; total protein intake in subjects and physical activity in subjects while at home. However there were no significant differences between total energy intake, physical activity in subjects while at schools and nutritional status in subjects.
\end{abstract}

Keywords: physical activity; school children; macronutrients intake; nutritional status

\begin{abstract}
ABSTRAK
Latar Belakang: Beberapa sekolah menerapkan proses pembelajaran dan kebijakan yang berbeda terkait aktivitas fisik dan penyelenggaraan makanan. Status gizi dapat dipengaruhi oleh asupan zat gizi dan aktivitas fisik. Tujuan penelitian ini untuk menganalisis perbedaan asupan energi, zat gizi makro, aktivitas fisik dan status gizi anak sekolah dasar di SD Negeri Lerep 05 dan SD Alam Ungaran.

Metode: Desain penelitian cross sectional dengan 44 subjek yang dihitung menggunakan rumus besar sampel 2 kelompok kategorik tidak berpasangan. Subjek berasal dari SD Negeri Lerep 05 dan SD Alam Ungaran. Asupan energi dan zat gizi makro diperoleh dari food record (3 hari: 2 weekdays, 1 weekend) dan dianalisis menggunakan Nutrisurvey. Aktivitas fisik diukur menggunakan Physical Activity Questionnaire for Children (PAQ-C). Status gizi berdasarkan Indeks Massa Tubuh menurut Umur (IMT/U). Data dianalisis dengan uji Chi-Square dan Mann-Whitney.

Hasil: Sebagian besar subjek dari SDN Lerep 05 memiliki asupan energi kurang selama di sekolah (90,9\%), tingkat aktivitas fisik sedang (63,6\%), status gizi berlebih IMT/U > ISD (45,5\%). Sebagian besar subjek dari SD Alam Ungaran memiliki asupan energi cukup selama di sekolah (40,9\%), tingkat aktivitas fisik sedang (45,5\%), status gizi normal $(68,2 \%)$. Terdapat perbedaan yang signifikan antara asupan energi $(p=0,001)$, protein $(p=0,001)$, karbohidrat $(p=0,013)$ subjek selama di sekolah, protein total subjek ( $p=0,002)$, aktivitas fisik subjek selama di rumah $(p=0,021)$. Tidak terdapat perbedaan antara asupan energi total subjek $(p=0,221)$, aktivitas fisik subjek di sekolah $(p=0,602)$, status gizi subjek $(p=0,167)$.

Simpulan: Terdapat perbedaan yang signifikan antara asupan energi, protein dan karbohidrat subjek selama di sekolah; asupan protein total subjek dan aktivitas fisik subjek selama di rumah. Namun tidak terdapat perbedaan yang signifikan antara asupan energi total subjek, aktivitas fisik subjek di sekolah dan status gizi subjek.
\end{abstract}

Kata kunci: aktivitas fisik; anak sekolah; asupan zat gizi makro; status gizi

\section{PENDAHULUAN}

Anak sekolah termasuk dalam salah satu kelompok rentan gizi. Kelompok rentan gizi adalah kelompok dalam masyarakat yang paling mudah mengalami gangguan terkait gizi atau kesehatan. ${ }^{1}$ Status gizi anak sekolah usia 5-12 tahun secara nasional berdasarkan data Riskedas 2018, menunjukkan prevalensi kurus sebesar $9,2 \%$ dan 
berat badan berlebih sebesar 20\%. Jawa Tengah termasuk dalam salah satu provinsi yang memiliki angka prevalesi gizi berlebih diatas prevalensi nasional. Prevalensi anak dengan berat badan berlebih yaitu sebesar $20,2 \%$ dan prevalensi kurus $8,6 \%{ }^{2}$

Status gizi dipengaruhi oleh berbagai faktor seperti asupan zat gizi dan aktivitas fisik anak. Asupan zat gizi dan aktivitas fisik akan mempengaruhi status kesehatan anak pada masa kini dan mendatang. ${ }^{3}$ Rerata tingkat kecukupan energi pada anak usia 5-12 tahun secara nasional berdasarkan Studi Diet Total (SDT) 2014 sebesar $86,5 \%$. Proporsi anak yang mengkonsumsi $<70 \%$ AKE sebesar 29,7\% dan 10,2\% $\geq 130 \%$ AKE. Rerata tingkat asupan energi pada anak di Jawa Tengah sebesar 88\%.4 Sementara laporan pengukuran aktivitas fisik Riskesdas 2018 menunjukkan 64,4\% anak usia 10-14 tahun memiliki aktivitas fisik yang kurang. ${ }^{2}$

Lingkungan sekolah menjadi salah satu faktor yang dapat berhubungan dengan status gizi anak karena anak menghabiskan sebagian besar waktunya di sekolah. ${ }^{5}$ Kondisi lingkungan sekolah seperti adanya kurikulum mengenai gizi dan kesehatan, adanya kunjungan tenaga kesehatan secara rutin ke sekolah, adanya aktivitas fisik sebelum kelas dimulai, kebiasaan jalan kaki/bersepeda ke sekolah, adanya informasi-informasi hidup sehat, adanya kantin sehat, kebijakan sekolah tentang makan minum dan aktivitas fisik, serta kerjasama dengan departemen kesehatan dilaporkan berhubungan dengan status gizi siswa. ${ }^{6}$ Penelitian lain juga melaporkan bahwa status obesitas pada anak sekolah berhubungan dengan kebiasaan sedentary $\geq 2$ kali per hari, kebiasaan makan $\geq 5$ kali per hari dan adanya permen yang dijual di sekolah. ${ }^{7}$ Lingkungan fisik sekolah seperti ketersediaan makanan jajanan yang sehat dan ketersediaan halaman yang luas juga berhubungan dengan menurunnya prevalensi obesitas pada siswa. ${ }^{8}$

Penyelenggaraan pendidikan dapat dilakukan oleh pemerintah ataupun masyarakat. ${ }^{9}$ Salah satu sekolah alam di Jawa Tengah yang termasuk dalam satuan pendidikan yang diselenggarakan oleh masyarakat adalah SD Alam Ungaran. Komunitas sekolah alam mendefinisikan sekolah alam sebagai sekolah dengan konsep pendidikan berbasis alam semesta yang menggunakan sumber daya alam di lingkungan sekitar sekolah. ${ }^{10}$ Banyak orangtua memilih SD Alam karena sekolah ini mengintegrasikan nilai-nilai kehidupan beragama sebagai pembentukan karakter. Lokasi SD Alam Ungaran berada dalam satu wilayah dengan beberapa sekolah dasar yang diselenggarakan oleh pemerintah, salah satunya SDN Lerep 05. Meskipun berada pada lokasi yang berdekatan kedua sekolah ini memiliki lingkungan sekolah yang berbeda baik dari segi pembelajaran maupun kebijakan.

Pembelajaran di SDN Lerep 05 pada umumnya dilakukan di dalam ruang kelas menggunakan kurikulum 2013. Terdapat kegiatan ekstrakurikuler pramuka dan rebana yang dilakukan rutin seminggu sekali. Sementara pembelajaran di SD Alam Ungaran lebih banyak dilakukan di luar ruangan. Kurikulum yang digunakan di sekolah alam adalah kurikulum perpaduan antara kurikulum nasional dan kurikulum khas sekolah alam. ${ }^{11}$ Kurikulum khas sekolah alam terdiri dari 4 pokok pengembangan yaitu pengembangan akhlak, logika, sifat kepemimpinan dan mental bisnis. ${ }^{12}$ Selain itu terdapat kegiatan ekstrakurikuler yang melibatkan aktivitas fisik tinggi seperti renang dan memanah. Penelitian yang dilakukan Trapasso et al di Inggris menunjukkan hasil terdapat perbedaan yang signifikan pada aktivitas fisik anak ketika mengikuti kegiatan sekolah alam dibandingkan dengan melakukan pembelajaran di dalam ruang kelas. ${ }^{13}$

SD Alam Ungaran menyelenggarakan pemberian makan siang melalui kegiatan katering sekolah. Kebijakan terkait makanan juga dilakukan seperti kewajiban membawa bekal bagi yang tidak mengikuti katering dan larangan membeli makanan di luar sekolah. ${ }^{14}$ SDN Lerep 05 tidak menyelenggarakan pemberian makan siang namun terdapat kantin yang menjual berbagai macam makanan dan anak juga dapat membeli makanan dari penjual di sekitar sekolah. Penelitian yang dilakukan Sunarti di Sukoharjo menunjukkan hasil anak yang menerima makan siang dari sekolah memiliki asupan energi dan protein yang lebih tinggi serta status gizi yang lebih baik. ${ }^{15}$

Studi pendahuluan dilakukan pada 10 anak di SD Alam Ungaran dan SDN Lerep 05. Hasil menunjukkan di SDN Lerep 05 terdapat $40 \%$ anak memiliki status gizi lebih, tingkat aktivitas sedang $80 \%$ dan asupan energi kurang sebanyak $60 \%$. Sementara di SD Alam Ungaran terdapat $80 \%$ anak memiliki status gizi normal, tingkat aktivitas fisik tinggi $60 \%$ dan asupan energi cukup sebanyak $60 \%$. Tujuan penelitian ini untuk menganalisis perbedaan asupan energi, zat gizi makro, aktivitas fisik dan status gizi anak sekolah dasar di SD Negeri Lerep 05 dan SD Alam Ungaran.

\section{METODE}

Penelitian ini menggunakan rancangan desain penelitian observasional dengan metode crosssectional. Penelitian dilakukan pada bulan AgustusSeptember 2019 di SDN Lerep 05 dan SD Alam Ungaran. Populasi terjangkau pada penelitian ini adalah seluruh anak SDN Lerep 05 dan SD Alam Ungaran. 
Besar subjek penelitian dihitung menggunakan rumus analitik kategorik tidak berpasangan dengan $\mathrm{Z} \alpha$ 95\%, Z $\beta$ 80\%, P1 0,79 dan P2 0,37. ${ }^{16,17}$ Berdasarkan perhitungan diperoleh besar subjek minimal untuk masing-masing sekolah sebanyak 20 subjek dengan total subjek minimal dalam penelitian ini adalah 40 subjek. Pada pelaksanaan pengumpulan data terdapat 50 subjek dengan 25 subjek dari masing-masing sekolah.

Kriteria eksklusi dalam penelitian ini yaitu tidak dapat mengikuti rangkaian penelitian, mengundurkan diri selama proses penelitian dan pindah sekolah. Satu orang subjek dari SD Alam tidak memenuhi kriteria inklusi karena berusia lebih dari 12 tahun dan terdapat 2 subjek SD Alam tereksklusi karena tidak mengisi form food record. Sementara 3 orang subjek dari SD Negeri tereksklusi. Sebanyak 2 subjek dieksklusi karena sakit pada saat proses pengambilan data dan 1 subjek tidak mengisi food record. Terdapat 44 subjek yang mengikuti penelitian ini secara penuh.

Pengambilan sampel menggunakan purposive sampling dengan kriteria inklusi yaitu bersedia menjadi sampel penelitian, anak sekolah berusia 9-12 tahun, tidak mengalami kelainan fisik dan mental serta tidak memiliki riwayat penyakit infeksi selama 1 bulan terakhir. Usia 9-12 tahun dipilih karena telah memenuhi syarat usia minimal subjek untuk mengisi PAQ-C. Selain itu pada usia ini anak telah masuk pada ranah kognitif yang lebih tinggi yaitu kemampuan menerapkan, sehingga dianggap mampu untuk mengisi kuisioner dan form food record yang diberikan. ${ }^{8}$

Variabel bebas dalam penelitian ini yaitu jenis sekolah meliputi SD Negeri (SDN Lerep 05) dan SD Alam (SD Alam Ungaran). Variabel terikat dalam penelitian ini yaitu asupan energi, asupan zat gizi makro (karbohidrat, protein, dan lemak), aktivitas fisik dan status gizi. Data karakteristik diambil menggunakan kuisioner. Data karakteristik subjek meliputi jenis kelamin, usia, pekerjaan orangtua, penghasilan orangtua, jumlah anggota keluarga, uang saku dan kegiatan ektrakulikuler. Penghasilan orangtua dan jumlah anggota keluarga digunakan untuk menghitung pendapatan/kapita/bulan yang kemudian dikategorikan berdasarkan standar di Kabupaten Semarang. Kategori pendapatan/kapita/bulan dibagi menjadi dua yaitu kurang (< Rp 377.674) dan cukup ( $\geq \operatorname{Rp~377.674).~}{ }^{19}$ Data uang saku dikategorikan berdasarkan Mean ideal (Mi) dan Standar Deviasi ideal (SDi). Kategori uang saku dibagi tiga yaitu rendah (< Mi-SDi atau < Rp 5.333), sedang (Mi-SDi s/d Mi+SDi atau Rp 5.333 s/d Rp 8.667) dan tinggi (> Mi+SDi atau > Rp 8.667).
Data ekstrakurikuler dikategorikan berdasarkan keaktifan subjek mengikuti kegiatan pramuka. Data ekstrakurikuler dikategorikan menjadi dua yaitu ikut dan tidak ikut.

Data antropometri meliputi tinggi badan dan berat badan. Pengukuran tinggi badan menggunakan microtoise dengan ketelitian $0,1 \mathrm{~cm}$ dan pengukuran berat badan dengan menggunakan timbangan injak digital dengan ketelitian $0,1 \mathrm{~kg}$. Hasil ukur Indeks Massa Tubuh menurut Umur (IMT/U) dikategorikan menjadi gizi kurang (<-2 SD), normal (-2 SD s.d. 1 $\mathrm{SD})$ dan gizi berlebih $(>1 \mathrm{SD}) .{ }^{20}$ Data asupan energi dan zat gizi makro diperoleh melalui food record. Pengisian food record dilakukan selama 3 hari dengan 2 hari sekolah dan 1 hari libur. Data yang diperoleh dianalisis menggunakan Nutrisurvey kemudian dibandingkan dengan AKG 2019. Data asupan dibagi menjadi tiga yaitu asupan di sekolah, asupan di rumah dan asupan total. Asupan total adalah seluruh makanan dan minuman yang dikonsumsi subjek selama satu hari yang kemudian dibandingkan dengan AKG. Asupan di sekolah adalah asupan makanan dan minuman yang dikonsumsi subjek selama berada di sekolah yang kemudian dibandingkan dengan $40 \%$ (selingan pagi dan makan siang) AKG. Asupan di rumah adalah asupan makanan dan minuman yang dikonsumsi subjek selama berada di rumah yang kemudian dibandingkan dengan 60\% (sarapan, selingan sore dan makan malam). Perbandingan asupan selama di sekolah dan di rumah ini berdasarkan rekomendasi kontribusi energi dan zat gizi yaitu sarapan $25 \%$, makan siang $30 \%$, makan malam $25 \%$ dan dua kali selingan masing-masing $10 \% .{ }^{21}$ Data asupan energi dan zat gizi makro dikategorikan menjadi kurang $(<90 \%)$, cukup $(90-110 \%)$ dan berlebih $(>110 \%)$. Data aktivitas fisik diukur menggunakan Physical Activity Questionnaire for Children (PAQ-C). Hasil ukur aktivitas fisik dikategorikan menjadi ringan (skor $\leq 2$ ), sedang (skor $>2$ s.d. $\leq 3$ ) dan tinggi (skor $>3) .{ }^{22}$ Analisis data menggunakan SPSS 22.0 dengan uji Chi-Square dan Mann-Whitney. ${ }^{23}$ Penelitian ini telah mendapat kelaikan etik dari Komisi Etik Penelitian Kesehatan Fakultas Kedokteran UNDIP No. 406/EC/KEPK/FK UNDIP/IX/2019.

\section{HASIL \\ Karakteristik Subjek}

Kegiatan ekstrakurikuler pramuka di SD Alam digabung pada jam pembelajaran sehingga 100\% subjek aktif mengikuti kegiatan tersebut, sementara di SD Negeri kegiatan dilakukan setelah jam pelajaran berakhir dan terdapat 45,5\% subjek SD Negeri yang tidak aktif mengikuti kegiatan pramuka (Tabel 1). 
Tabel 1. Karakteristik Subjek

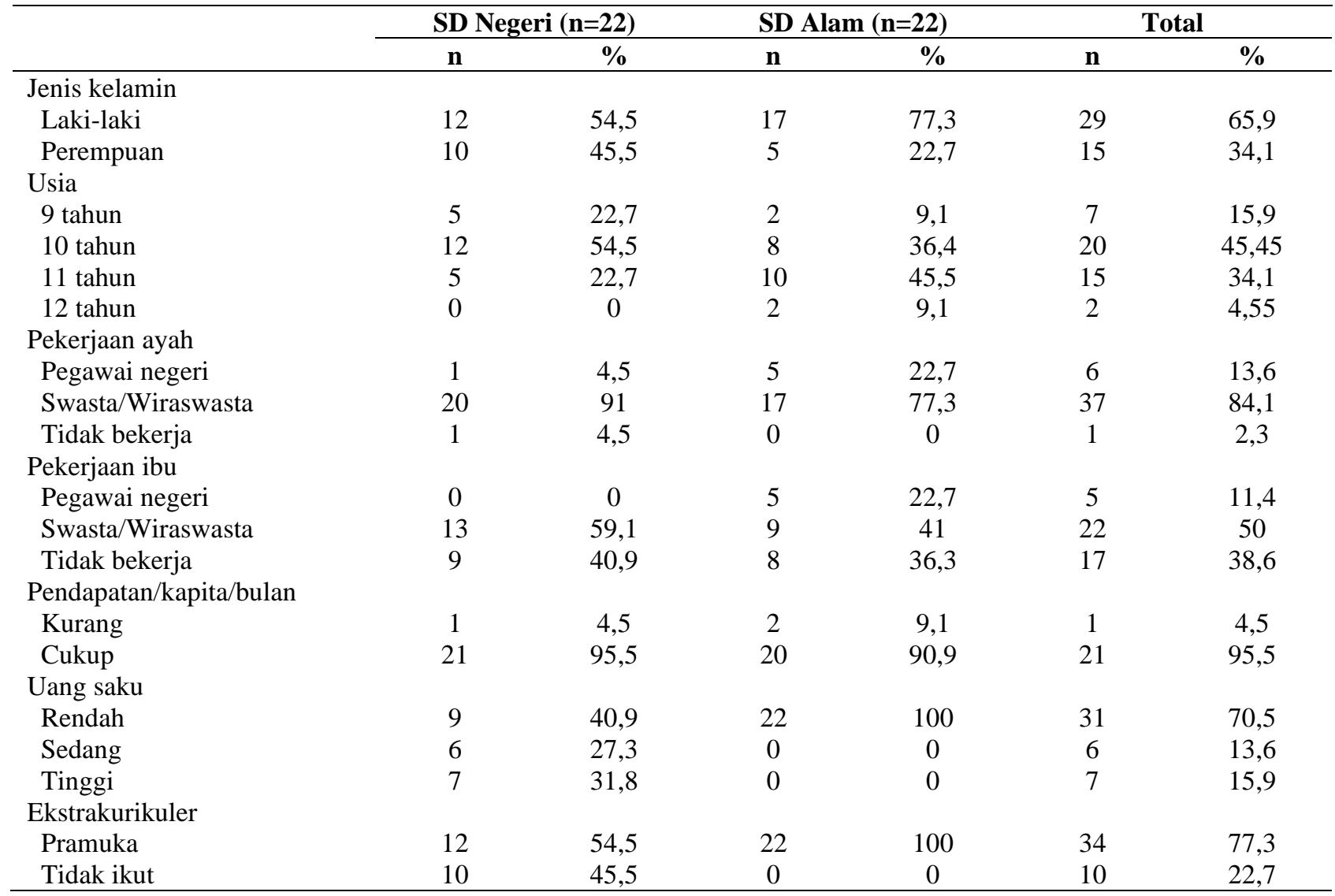

Tabel 2. Distribusi Frekuensi Asupan Energi dan Zat Gizi Makro

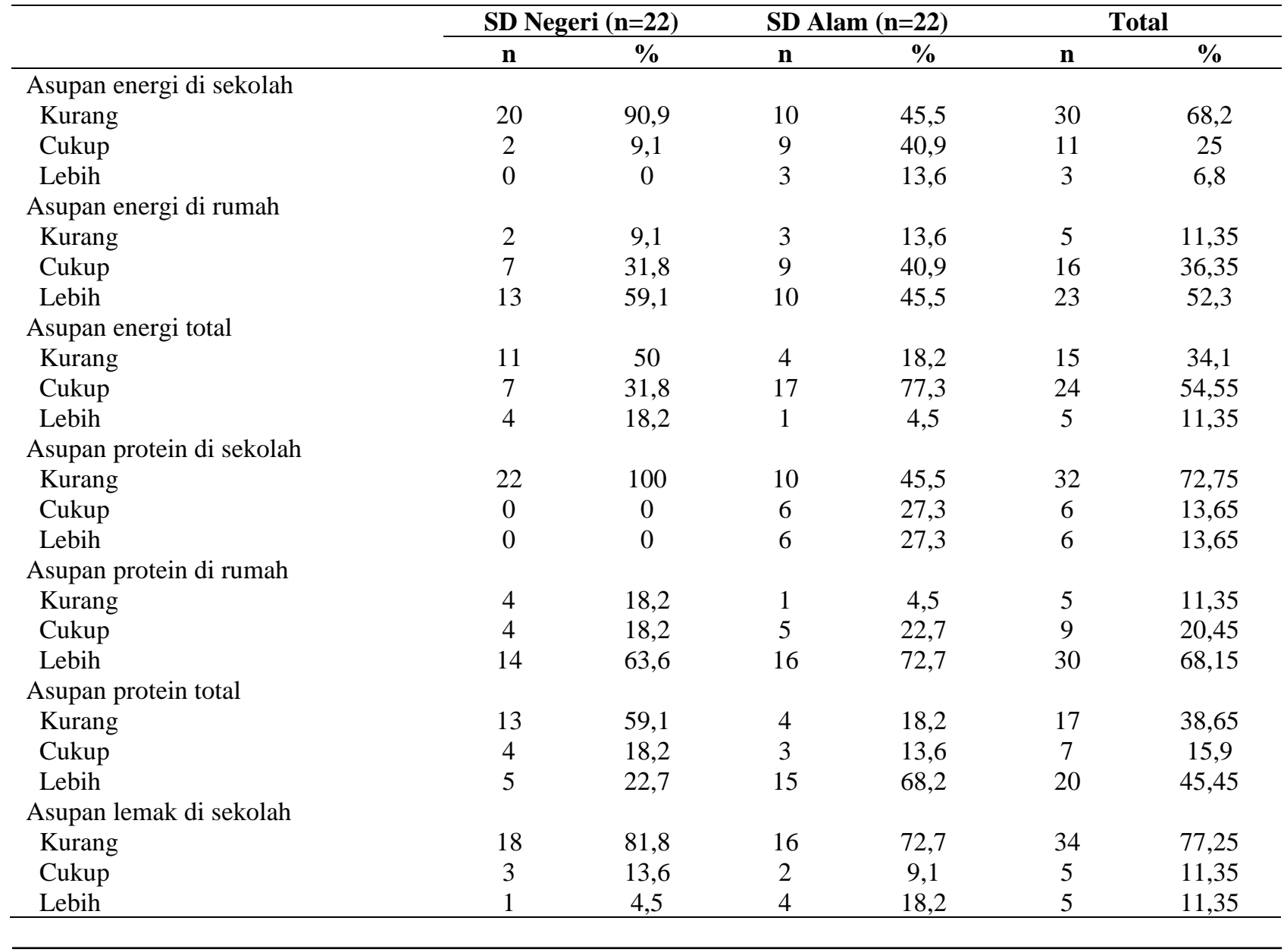


Lanjutan ...

\begin{tabular}{|c|c|c|c|c|c|c|}
\hline & \multicolumn{2}{|c|}{ SD Negeri $(n=22)$} & \multicolumn{2}{|c|}{ SD Alam (n=22) } & \multicolumn{2}{|c|}{ Total } \\
\hline & $\mathbf{n}$ & $\%$ & $\mathbf{n}$ & $\%$ & $\mathbf{n}$ & $\%$ \\
\hline \multicolumn{7}{|c|}{ Asupan lemak di rumah } \\
\hline Kurang & 8 & 36,4 & 7 & 31,8 & 15 & 34,1 \\
\hline Cukup & 4 & 18,2 & 7 & 31,8 & 11 & 25 \\
\hline Lebih & 10 & 45,5 & 8 & 36,4 & 18 & 40,95 \\
\hline \multicolumn{7}{|c|}{ Asupan lemak total } \\
\hline Kurang & 12 & 54,5 & 10 & 45,5 & 22 & 50 \\
\hline Cukup & 10 & 45,5 & 6 & 27,3 & 16 & 36,4 \\
\hline Lebih & 7 & 31,8 & 6 & 27,3 & 13 & 29,55 \\
\hline \multicolumn{7}{|c|}{ Asupan karbohidrat di sekolah } \\
\hline Kurang & 21 & 95,5 & 14 & 63,6 & 35 & 79,55 \\
\hline Cukup & 0 & 0 & 5 & 22,7 & 5 & 11,35 \\
\hline Lebih & 1 & 4,5 & 3 & 13,6 & 4 & 9,05 \\
\hline \multicolumn{7}{|c|}{ Asupan karbohidrat di rumah } \\
\hline Kurang & 4 & 18,2 & 6 & 27,3 & 10 & 22,75 \\
\hline Cukup & 7 & 31,8 & 9 & 40,9 & 16 & 36,35 \\
\hline Lebih & 11 & 50 & 7 & 31,8 & 18 & 40,9 \\
\hline \multicolumn{7}{|c|}{ Asupan karbohidrat total } \\
\hline Kurang & 12 & 54,5 & 10 & 45,5 & 22 & 50 \\
\hline Cukup & 8 & 36,4 & 11 & 50 & 19 & 43,2 \\
\hline Lebih & 2 & 9,1 & 1 & 4,5 & 3 & 6,8 \\
\hline
\end{tabular}

Tabel 3. Distribusi Frekuensi Aktivitas Fisik dan Status Gizi

\begin{tabular}{|c|c|c|c|c|c|c|}
\hline & \multicolumn{2}{|c|}{ SD Negeri $(n=22)$} & \multicolumn{2}{|c|}{ SD Alam $(n=22)$} & \multicolumn{2}{|c|}{ Total } \\
\hline & $\mathbf{n}$ & $\%$ & $\mathbf{n}$ & $\%$ & $\mathbf{n}$ & $\%$ \\
\hline \multicolumn{7}{|c|}{ Aktivitas fisik di sekolah } \\
\hline Ringan & 3 & 13,6 & 4 & 18,2 & 7 & 15,9 \\
\hline Sedang & 14 & 63,6 & 10 & 45,5 & 24 & 54,55 \\
\hline Tinggi & 5 & 22,7 & 8 & 36,4 & 13 & 29,55 \\
\hline \multicolumn{7}{|c|}{ Aktivitas fisik di rumah } \\
\hline Ringan & 2 & 9,1 & 9 & 40,9 & 11 & 25 \\
\hline Sedang & 14 & 63,6 & 6 & 27,3 & 20 & 45,45 \\
\hline Tinggi & 6 & 27,3 & 7 & 31,8 & 13 & 29,55 \\
\hline \multicolumn{7}{|c|}{ Aktivitas fisik total } \\
\hline Ringan & 2 & 9,1 & 6 & 27,3 & 8 & 18,2 \\
\hline Sedang & 16 & 72,7 & 10 & 45,5 & 26 & 59,1 \\
\hline Tinggi & 4 & 18,2 & 6 & 27,3 & 10 & 22,75 \\
\hline \multicolumn{7}{|l|}{ Status Gizi } \\
\hline Gizi kurang & 0 & 0 & 1 & 4,5 & 1 & 2,25 \\
\hline Normal & 12 & 54,5 & 15 & 68,2 & 27 & 61,35 \\
\hline Gizi lebih & 10 & 45,5 & 6 & 27,3 & 16 & 36,4 \\
\hline
\end{tabular}

Tabel 4. Distribusi Frekuensi Jajanan Subjek SD Negeri

\begin{tabular}{lcc}
\hline & n & \% \\
\hline Minuman berasa & 3 & 13,6 \\
Snack kemasan & 4 & 18,2 \\
Mie instan & 4 & 18,2 \\
Es lilin & 1 & 4,5 \\
Nasi bungkus (nasi goreng, nasi rames) & 4 & 18,2 \\
Donat & 2 & 9,1 \\
Tahu bulat & 1 & 4,5 \\
Papeda telur & 1 & 4,5 \\
Sosis dan bakso tusuk & 2 & 9,1 \\
\hline
\end{tabular}


Tabel 5. Menu Katering Makan Siang SD Alam

\begin{tabular}{lllll}
\hline Senin & Selasa & Rabu & Kamis & Jumat \\
\hline Nasi & Nasi & Nasi & Nasi & Nasi \\
Tempe goreng & Bandeng goreng & Tahu crispy & Telur bulat kecap & Ayam kecap \\
$\begin{array}{l}\text { Sop sayur (kol, } \\
\text { wortel, buncis, }\end{array}$ & Bakmi sayur (wortel, & Oseng sayur & Oseng kangkung & Sayur bayam \\
kentang) dan ayam & sawi) & (brokoli, wortel, & & \\
& & $\begin{array}{l}\text { buncis, kol) dan } \\
\text { sosis }\end{array}$ & & \\
\hline
\end{tabular}

Tabel 6. Perbedaan Pendapatan dan Uang Saku

\begin{tabular}{|c|c|c|c|c|c|}
\hline & \multicolumn{2}{|c|}{ SD Negeri $(n=22)$} & \multicolumn{2}{|c|}{ SD Alam $(n=22)$} & \multirow[b]{2}{*}{$p$} \\
\hline & $\mathbf{n}$ & $\%$ & $\mathbf{n}$ & $\%$ & \\
\hline \multicolumn{6}{|c|}{ Pendapatan/kapita/bulan } \\
\hline Kurang & 1 & 4,5 & 2 & 9,1 & \multirow{2}{*}{$0,554^{\mathrm{a}}$} \\
\hline Cukup & 21 & 95,5 & 20 & 90,9 & \\
\hline \multicolumn{6}{|c|}{ Uang saku } \\
\hline Rendah & 9 & 40,9 & 22 & 100 & \multirow{3}{*}{$0,001^{\mathrm{a}^{*}}$} \\
\hline Sedang & 6 & 27,3 & 0 & 0 & \\
\hline Tinggi & 7 & 31,8 & 0 & 0 & \\
\hline
\end{tabular}

Pada tabel 2 menunjukkan bahwa selama di sekolah sebagian besar subjek dari SD Alam memiliki asupan energi dan zat gizi makro yang lebih tinggi dibandingkan subjek dari SD Negeri. Sebanyak 40,9\% subjek dari SD Alam memiliki asupan energi cukup, sementara 90,9\% subjek dari SD Negeri selama di sekolah cenderung memiliki asupan energi kurang. Pada asupan lemak subjek dari kedua sekolah memiliki asupan yang kurang $(77,25 \%)$.

Pada tabel 3 menunjukkan bahwa sebagian besar subjek memiliki status gizi normal $(61,35 \%)$. Aktivitas fisik subjek dari SD Negeri dan SD Alam selama di sekolah sebagian besar termasuk kategori sedang $(54,55 \%)$.

Pada tabel 5 menunjukkan penyelenggaraan makan di SD Alam dilakukan dengan memberikan makan siang kepada anak dengan menu yang terdiri dari makanan pokok, lauk pauk dan sayur.
Pada tabel 6 menunjukkan tidak terdapat perbedaan yang signifikan pada pendapatan/kapita/bulan subjek dari kedua sekolah. Sebagian besar pendapatan/kapita/bulan orangtua subjek tergolong cukup $(90,9 \%)$. Terdapat perbedaan yang signifikan pada uang saku subjek. Uang saku subjek SD Alam tergolong rendah karena terdapat kebijakan pembatasan uang saku.

\section{Perbedaan Asupan Energi dan Zat Gizi Makro}

Berdasarkan hasil analisis terdapat perbedaan yang signifikan selama di sekolah pada asupan energi, protein dan karbohidrat. Namun tidak terdapat perbedaan yang signifikan pada asupan lemak. Sebanyak 81,8\% subjek SD Negeri dan 72,7\% subjek SD Alam memiliki asupan lemak yang tergolong kurang. Pada asupan energi dan zat gizi makro selama di rumah tidak terdapat perbedaan yang signifikan. Sedangkan pada asupan zat gizi total terdapat perbedaan yang signifikan pada asupan protein.

Tabel 7. Perbedaan Asupan Energi dan Zat Gizi Makro

\begin{tabular}{|c|c|c|c|c|c|}
\hline & \multicolumn{2}{|c|}{ SD Negeri $(n=22)$} & \multicolumn{2}{|c|}{ SD Alam $(n=22)$} & \multirow{2}{*}{$p$} \\
\hline & $\mathbf{n}$ & $\%$ & $\mathbf{n}$ & $\%$ & \\
\hline \multicolumn{6}{|c|}{ Asupan energi di sekolah } \\
\hline Kurang & 20 & 90,9 & 10 & 45,5 & $0,001^{\mathrm{a}^{*}}$ \\
\hline Cukup & 2 & 9,1 & 9 & 40,9 & \\
\hline Lebih & 0 & 0 & 3 & 13,6 & \\
\hline \multicolumn{6}{|c|}{ Asupan energi di rumah } \\
\hline Kurang & 2 & 9,1 & 3 & 13,6 & $0,368^{\mathrm{a}}$ \\
\hline Cukup & 7 & 31,8 & 9 & 40,9 & \\
\hline Lebih & 13 & 59,1 & 10 & 45,5 & \\
\hline \multicolumn{6}{|c|}{ Asupan energi total } \\
\hline Kurang & 11 & 50 & 4 & 18,2 & $0,221^{\mathrm{a}}$ \\
\hline Cukup & 7 & 31,8 & 17 & 77,3 & \\
\hline Lebih & 4 & 18,2 & 1 & 4,5 & \\
\hline
\end{tabular}


Lanjutan ...

\begin{tabular}{|c|c|c|c|c|c|}
\hline & \multicolumn{2}{|c|}{ SD Negeri $(n=22)$} & \multicolumn{2}{|c|}{ SD Alam $(n=22)$} & \multirow{2}{*}{$p$} \\
\hline & $\mathbf{n}$ & $\%$ & $\mathbf{n}$ & $\%$ & \\
\hline \multicolumn{6}{|c|}{ Asupan protein di sekolah } \\
\hline Kurang & 22 & 100 & 10 & 45,5 & $0,001^{\mathrm{a}^{*}}$ \\
\hline Cukup & 0 & 0 & 6 & 27,3 & \\
\hline Lebih & 0 & 0 & 6 & 27,3 & \\
\hline \multicolumn{6}{|c|}{ Asupan protein di rumah } \\
\hline Kurang & 4 & 18,2 & 1 & 4,5 & $0,391^{\mathrm{a}}$ \\
\hline Cukup & 4 & 18,2 & 5 & 22,7 & \\
\hline Lebih & 14 & 63,6 & 16 & 72,7 & \\
\hline \multicolumn{6}{|c|}{ Asupan protein total } \\
\hline Kurang & 13 & 59,1 & 4 & 18,2 & $0,002^{\mathrm{a}^{*}}$ \\
\hline Cukup & 4 & 18,2 & 3 & 13,6 & \\
\hline Lebih & 5 & 22,7 & 15 & 68,2 & \\
\hline \multicolumn{6}{|c|}{ Asupan lemak di sekolah } \\
\hline Kurang & 18 & 81,8 & 16 & 72,7 & $0,387^{\mathrm{a}}$ \\
\hline Cukup & 3 & 13,6 & 2 & 9,1 & \\
\hline Lebih & 1 & 4,5 & 4 & 18,2 & \\
\hline \multicolumn{6}{|c|}{ Asupan lemak di rumah } \\
\hline Kurang & 8 & 36,4 & 7 & 31,8 & $0,575^{b}$ \\
\hline Cukup & 4 & 18,2 & 7 & 31,8 & \\
\hline Lebih & 10 & 45,5 & 8 & 36,4 & \\
\hline \multicolumn{6}{|c|}{ Asupan lemak total } \\
\hline Kurang & 12 & 54,5 & 10 & 45,5 & $0,798^{\mathrm{a}}$ \\
\hline Cukup & 10 & 45,5 & 6 & 27,3 & \\
\hline Lebih & 7 & 31,8 & 6 & 27,3 & \\
\hline \multicolumn{6}{|c|}{ Asupan karbohidrat di sekolah } \\
\hline Kurang & 22 & 100 & 14 & 63,6 & $0,002^{\mathrm{a}^{*}}$ \\
\hline Cukup & 0 & 0 & 5 & 22,7 & \\
\hline Lebih & 0 & 0 & 3 & 13,6 & \\
\hline \multicolumn{6}{|c|}{ Asupan karbohidrat di rumah } \\
\hline Kurang & 4 & 18,2 & 6 & 27,3 & $0,463^{\mathrm{b}}$ \\
\hline Cukup & 7 & 31,8 & 9 & 40,9 & \\
\hline Lebih & 11 & 50 & 7 & 31,8 & \\
\hline \multicolumn{6}{|c|}{ Asupan karbohidrat total } \\
\hline Kurang & 13 & 59,1 & 10 & 45,5 & $0,500^{\mathrm{a}}$ \\
\hline Cukup & 7 & 31,8 & 11 & 50 & \\
\hline Lebih & 2 & 9,1 & 1 & 4,5 & \\
\hline
\end{tabular}

${ }^{\text {a }}$ Mann-Whitney test ${ }^{\mathrm{b}}$ Chi-Square test $; *$ Signifikan $\mathrm{p}<0,05$

Tabel 8. Perbedaan Aktivitas Fisik dan Status Gizi

\begin{tabular}{|c|c|c|c|c|c|}
\hline & \multicolumn{2}{|c|}{ SD Negeri (n=22) } & \multicolumn{2}{|c|}{ SD Alam (n=22) } & \multirow[b]{2}{*}{$p$} \\
\hline & $\mathbf{n}$ & $\%$ & $\mathbf{n}$ & $\%$ & \\
\hline \multicolumn{6}{|c|}{ Aktivitas fisik di sekolah } \\
\hline Ringan & 3 & 13,6 & 4 & 18,2 & \multirow{3}{*}{$0,602^{\mathrm{a}}$} \\
\hline Sedang & 14 & 63,6 & 10 & 45,5 & \\
\hline Tinggi & 5 & 22,7 & 8 & 36,4 & \\
\hline \multicolumn{6}{|c|}{ Aktivitas fisik di rumah } \\
\hline Ringan & 2 & 9,1 & 9 & 40,9 & \multirow{3}{*}{$0,021^{\mathrm{b}^{*}}$} \\
\hline Sedang & 14 & 63,6 & 6 & 27,3 & \\
\hline Tinggi & 6 & 27,3 & 7 & 31,8 & \\
\hline \multicolumn{6}{|c|}{ Aktivitas fisik total } \\
\hline Ringan & 2 & 9,1 & 6 & 27,3 & \multirow{3}{*}{$0,670^{\mathrm{a}}$} \\
\hline Sedang & 16 & 72,7 & 10 & 45,5 & \\
\hline Tinggi & 4 & 18,2 & 6 & 27,3 & \\
\hline \multicolumn{6}{|l|}{ Status Gizi } \\
\hline Gizi kurang & 0 & 0 & 1 & 4,5 & \multirow[t]{3}{*}{$0,167^{\mathrm{a}}$} \\
\hline Normal & 12 & 54,5 & 15 & 68,2 & \\
\hline Gizi lebih & 10 & 45,5 & 6 & 27,3 & \\
\hline
\end{tabular}




\section{Perbedaan Aktivitas Fisik dan Status Gizi}

Berdasarkan hasil analisis tidak terdapat perbedaan yang signifikan pada status gizi subjek. Aktifitas fisik selama di rumah memiliki perbedaan yang signifikan dimana subjek dari SD Negeri memiliki aktifitas sedang sebesar $63,6 \%$ dan $27,3 \%$ subjek dari SD Alam memiliki aktivitas fisik ringan (Tabel 8).

\section{PEMBAHASAN}

\section{Perbedaan Asupan Energi dan Zat Gizi Makro}

Berdasarkan hasil penelitian terdapat perbedaan yang signifikan pada asupan energi subjek selama di sekolah $(\mathrm{p}=0,001)$. Terdapat $40,9 \%$ subjek SD Alam yang memiliki asupan energi dalam kategori cukup sementara 90,9\% subjek SD Negeri memiliki asupan energi kurang. Hal ini dapat disebabkan oleh kebijakan pemberian makan siang di SD Alam. Setiap anak mendapatkan makan siang yang terdiri dari makanan pokok, lauk pauk dan sayur. Hasil penelitian ini sesuai dengan penelitian sebelumnya yang menyatakan bahwa anak yang mendapatkan makan siang dari sekolah memiliki asupan energi yang lebih baik. ${ }^{24}$ Energi dihasilkan dari zat gizi makro yang terdiri dari protein, lemak dan karbohidrat. ${ }^{25}$

Hasil penelitian pada asupan karbohidrat $(p=0,002)$ dan protein $(p=0,001)$ selama di sekolah juga menunjukkan perbedaan yang signifikan. Sebanyak 22,7\% subjek SD Alam memiliki asupan karbohidrat cukup, sementara seluruh subjek SD Negeri memiliki asupan karbohidrat kurang. Sebanyak 27,3\% subjek SD Alam memiliki asupan protein cukup dan seluruh subjek SD Negeri memiliki asupan protein kurang. Hal ini dapat disebabkan oleh menu makan siang di SD Alam yang menyediakan makanan pokok sumber karbohirat berupa nasi dan lauk pauk sumber protein baik hewani maupun nabati. Kantin di SD Negeri sudah menjual berbagai makanan termasuk makanan pokok dan lauk pauk namun makanan yang dijual masih dalam porsi kecil dan kualitas protein yang masih kurang. Protein dikatakan adekuat apabila mengandung semua asam amino esensial dalam jumlah cukup dan mudah di cerna oleh tubuh. Protein berkualitas tinggi ada dalam protein hewani seperti ikan, daging dan telur. Konsumsi protein tambahan juga dapat diperoleh dari protein nabati seperti kacang-kacangan, tahu dan tempe. ${ }^{25}$ Selain itu, meskipun terdapat perbedaan yang signifikan pada uang saku dimana subjek SD Negeri memiliki uang saku yang lebih tinggi namun subjek lebih suka membeli makanan ringan saat jam istirahat seperti snack kemasan (hasil tabel 4). Penelitian lain melaporkan bahwa konsumsi pada anak usia 9-12 tahun didominasi oleh konsumsi snack. Sebanyak 27\% subjek mengonsumsi snack dengan frekuensi sering, sebanyak 51,4\% subjek mengonsumsi lebih dari 2 jenis snack dan $87,9 \%$ subjek memiliki kontribusi energi dari snack lebih dari $10 \%$ asupan energi. Selain itu, 37,1\% subjek memiliki asupan energi yang berlebih $(>100 \%) .{ }^{26}$ Konsumsi makanan ringan mengandung monosodium glutamate/MSG sebagai camilan dapat menyebabkan ketidakseimbangan status gizi karena merupakan makanan padat kalori namun rendah gizi. Hal ini sejalan dengan penelitian di China yang melaporkan bahwa konsumsi makanan mengandung MSG terbukti menurunkan asupan makan siang pada subjek obesitas. ${ }^{27}$

Pada asupan lemak tidak terdapat perbedaan yang signifikan $(\mathrm{p}=0,387)$. Sebagian besar subjek dari kedua sekolah memiliki asupan lemak kurang. Hal ini dapat disebabkan oleh kurangnya konsumsi sumber lemak pada kedua kelompok. Meskipun subjek di SD Alam mendapatkan asupan lemak dari menu makan siang seperti minyak pada daging ayam, namun porsi yang dikonsumsi belum dapat memenuhi kebutuhan lemak. Sumber lemak dibagi menjadi menjadi lemak hewani dan nabati. Lemak hewani berasal dari binatang seperti hewan ternak dan ikan. Lemak nabati seperti kelapa, santan dan minyak dari berbagai bijibijian. Sumber lemak lain terdapat dalam kacang tanah, kacang mete, kenari, biji kemiri dan sejenisnya. ${ }^{28}$

Tidak terdapat perbedaan yang signifikan pada total asupan energi subjek $(p=0,221)$. Hal ini dapat disebabkan oleh tidak adanya perbedaan asupan energi dan zat gizi makro selama di rumah ( $p>0,05)$. Sebanyak 59,1\% subjek SD Negeri dan 45,5\% subjek SD Alam memiliki asupan berlebih selama di rumah. Asupan selama di rumah terdiri dari makan pagi, selingan sore dan makan malam. Namun, sebagian besar subjek dari SD Negeri mengonsumsi makan siang di rumah. Terdapat $10(45,5 \%)$ subjek dari SD Alam yang memiliki asupan zat gizi berlebih selama di rumah. Hal ini disebabkan 3 subjek yang memiliki kebiasaan frekuensi makan 4 kali dalam sehari, 4 subjek yang mengonsumsi lauk hewani dalam porsi berlebih dengan pengolahan digoreng dan 3 subjek yang mengonsumsi selingan sore dalam porsi besar. Asupan zat gizi juga dipengaruhi oleh kondisi sosial ekonomi. ${ }^{29}$ Hasil analisis bivariat pendapatan/kapita/bulan menunjukkan tidak ada perbedaan yang signifikan. Sebanyak 90,9\% penghasilan orangtua subjek berada diatas standar pendapatan/kapita/bulan. Total asupan zat gizi makro (protein, lemak dan karbohidrat) yang memiliki perbedaan signifikan hanya protein $(\mathrm{p}=0,002)$. Subjek dari SD Alam memiliki asupan protein yang lebih tinggi dibandingkan subjek di SD Negeri. Lauk pauk pada menu makan siang di sekolah memberikan kontribusi pada total asupan protein. 


\section{Perbedaan Aktivitas Fisik}

Berdasarkan uji statistik terdapat perbedan aktivitas fisik selama di rumah $(\mathrm{p}=0,021)$. Selama di rumah 63,6\% subjek dari SD Negeri memiliki tingkat aktivitas fisik sedang, sedangkan $40,9 \%$ subjek dari SD Alam memiliki aktivitas fisik ringan. Frekuensi dan intensitas mempengaruhi tingkat aktivitas fisik. ${ }^{30}$ Aktivitas fisik yang lebih tinggi pada subjek SD Negeri dapat disebabkan oleh lokasi tempat tinggal subjek yang saling berdekatan, sehingga subjek sering bermain bersama. Rata-rata subjek SD Negeri bermain 3-4 kali selama seminggu setelah pulang sekolah. Permainan yang biasa dilakukan melibatkan aktivitas fisik seperti kejar-kejaran, lompat tali dan permainan olahraga yang meningkatkan intensitas aktivitas fisik.

Tidak terdapat perbedaan yang signifikan pada aktivitas fisik di sekolah $(\mathrm{p}=0,602)$ dan aktivitas fisik total $(\mathrm{p}=0,670)$. Hasil penelitian ini sejalan dengan penelitian yang dilakukan di Finlandia yang menyatakan bahwa tidak terdapat perbedaan aktivitas fisik selama di sekolah pada anak yang mendapatkan dan tidak mendapatkan intervensi pembelajaran di luar ruangan. Hal ini disebabkan pembelajaran luar ruangan di lingkungan yang bebas membuat beberapa siswa mengambil kesempatan untuk lebih banyak bersantai, sementara pada pembelajaran di dalam ruangan anak lebih aktif bermain pada jam istirahat. ${ }^{31}$ Sebanyak 63,6\% subjek SD Negeri dan 45,5\% subjek SD Alam memiliki tingkat aktivitas fisik sedang selama di sekolah. Hasil penelitian ini sejalan dengan penelitian yang dilakukan di Salatiga dimana anak SD Negeri memiliki tingkat aktivitas fisik sedang. ${ }^{32}$ Pembelajaran di luar rungan dan kegiatan ekstrakurikuler yang melibatkan aktivitas fisik di SD Alam belum dapat berkontribusi pada aktivitas fisik subjek. Hal ini dapat disebabkan oleh kegiatan ekstrakurikuler yang tidak diikuti oleh seluruh siswa dan banyak pembelajaran di luar ruangan yang tidak melibatkan intensitas aktivitas fisik tinggi, seperti observasi. Pada jam istirahat kedua selain makan siang sebagian besar subjek (30\%) menghabiskan waktunya untuk duduk mengobrol.

\section{Perbedaan Status Gizi}

Hasil penelitian menunjukkan tidak ada perbedaan status gizi yang signifikan $(p=0,167)$. Hasil penelitian ini sesuai dengan penelitian sebelumnya yang menyatakan tidak terdapat perbedaan status gizi pada anak yang menerima dan tidak menerima makan siang di sekolah $(\mathrm{p}=0,641) .{ }^{33}$ Hal ini dapat terjadi karena tidak terdapat perbedaan yang signifikan pada total asupan energi dan total aktivitas fisik. Sebanyak 54,5\% subjek SD Negeri dan $68,2 \%$ subjek SD Alam memiliki status gizi normal. Keseimbangan energi perlu dijaga dengan menyesuaikan asupan dan aktivitas fisik untuk mencegah terjadinya masalah status gizi. ${ }^{34}$ Sebagian besar subjek yang berstatus gizi normal memiliki asupan cukup dan tingkat aktivitas fisik sedang.

Tidak terdapatnya perbedaan yang signifikan pada status gizi subjek di kedua sekolah dapat disebabkan oleh total asupan energi subjek yang tidak memiliki perbedaan signifikan ( $\mathrm{p}=0,221)$. Penelitian sebelumnya yang dilakukan di kota Sukabumi juga menunjukkan hasil tidak ada perbedaan pada asupan energi anak yang mengikuti penyelenggaraan makanan dan tanpa penyelenggaraan makanan $(\mathrm{p}=0,359) .{ }^{33}$ Status gizi dipengaruhi langsung oleh konsumsi pangan. ${ }^{35}$ Meskipun subjek di SD Alam mendapatkan makan siang dari sekolah dan terdapat perbedaan yang signifikan pada asupan selama di sekolah $(\mathrm{p}<0,05)$, namun selama di rumah asupan dari kedua kelompok subjek tidak memiliki perbedaan yang signifikan ( $p>0,05)$.

Status gizi secara tidak langsung dipengaruhi oleh faktor sosial ekonomi. ${ }^{35}$ Tidak terdapat perbedaan yang signifikan pada pendapatan/kapita/bulan orangtua subjek $(p=0,554)$. Meski subjek SD Negeri memiliki uang saku lebih banyak, namun uang saku ini tidak dihabiskan seluruhnya dan hanya dibelanjakan untuk membeli makanan ringan selama di sekolah yang menyebabkan kurangnya kontribusi pada asupan anak. Penelitian sebelumnya yang dilakukan pada anak sekolah dasar menyatakan bahwa tidak terdapat perbedaan antara status gizi dan nominal uang saku $(\mathrm{p}=0,083){ }^{36}$

\section{SIMPULAN}

Terdapat perbedaan yang signifikan pada asupan energi, protein dan karbohidrat selama di sekolah; asupan protein total dan aktivitas fisik selama di rumah. Namun tidak terdapat perbedaan yang signifikan pada asupan lemak di sekolah; asupan zat gizi selama di rumah; asupan energi, lemak dan karbohidrat total, aktivitas fisik di sekolah dan aktivitas fisik total, serta status gizi.

\section{SARAN}

Penyelenggaraan makan di sekolah perlu dilakukan dengan memperhatikan siklus menu dan kebutuhan asupan zat gizi anak. Jika sekolah tidak menyelenggarakan pemberian makan siang diharapkan dapat menghimbau anak untuk membawa bekal dari rumah dan memberikan edukasi terkait pemilihan makanan. Anak sebaiknya meningkatkan aktivitas fisik di rumah maupun di sekolah. Diperlukan penelitian lebih lanjut dengan memadukan desain kualitatif kuantitatif dan menggunakan metode food recall untuk mengumpulkan data asupan. Selain itu, diperlukan 
strategi promosi gizi terkait optimalisasi asupan zat gizi anak selama di rumah dan di sekolah.

\section{DAFTAR PUSTAKA}

1. Notoatmodjo S. Kesehatan masyarakat ilmu dan seni. Jakarta: Rineka Cipta; 2011. 229 p.

2. Badan Penelitian dan Pengembangan Kesehatan A. Riset Kesehatan Dasar (RISKESDAS) 2018. Jakarta; 2018.

3. Wooldridge NH. Child and preadolescent nutrition. In: Brown JE, editor. Nutrition Through the Life Cycle. 4th ed. Wadsworth, USA; 2011. p. 311.

4. Siswanto. Studi Diet Total: Survei Konsumsi Makanan Individu Indonesia 2014. Jakarta: Badan Penelitian dan Pengembangan Kesehatan; 2014.

5. Ogata B, Feucht S, Lucas B. Nutrition in childhood. In: Krause's Food and The Nutrition Care Process. 14th ed. Missouri: Elsevier Inc. St Louis; 2017. p. 323.

6. Wafa SW, Ghazalli R. Association between the school environment and children's body mass index in Terengganu: A cross sectional study. PLoS One. 2020;15(4):1-17.

7. Andrade De Medeiros Moreira R, Ricardo Moreira T, Dias Da Costa G, Vidigal Castro LC, Minardi Mitre Cotta R. Multilevel analysis of factors that influence overweight in children: Research in schools enrolled in northern Brazil School Health Program. BMC Pediatr. 2020;20(1):1-18.

8. Goncalves VS, Duarte EC, Dutra ES, Barufaldi LA, Carvalho KM. Characteristics of the school food environment associated with hypertension and obesity in Brazilian adolescents: A multilevel analysis of the Study of Cardiovascular Risks in Adolescents (ERICA). Public Health Nutr. 2019;22(14):2625-34.

9. Pemerintah Republik Indonesia. Peraturan Pemerintah Republik Indonesia Nomor 17 Tahun 2010 Tentang Pengelolaan dan Penyelenggaraan Pendidikan.

10. Komunitas Sekolah Alam. Menemukan sekolah yang membebaskan, perjalanan menggapai sekolah yang mendidik anak menjadi manusia berkarakter. Depok: Kawan Pustaka; 2005.

11. Syafril, Zelhendri Z. Dasar-dasar ilmu pendidikan. Depok: Kencana; 2017. 149-150 p.

12. School of Universe. Kurikulum sekolah alam. [Internet]. Bogor: School of Universe; 2019 [cited 30 October 2019]. Available from: http://school-ofuniverse.com/profile/kurikulum\#.X7EAPmgzY $2 \mathrm{w}$.

13. Trapasso E, Knowles Z, Boddy L, Newson L,
Sayers J, Austin C. Exploring gender differences within forest schools as a physical activity intervention. J Child. 2018;5(138):1-18.

14. Yudistira C. Implementasi pendidikan karakter peduli lingkungan di Sekolah Alam Ungaran Kabupaten Semarang. Universitas Semarang; 2014. Available from: https://lib.unnes.ac.id/23071/1/4401408114.pdf.

15. Sunarti. Perbedaan asupan energi, protein dan status gizi anak usia pra sekolah di sekolah dengan model school feeding dan non school feeding. KESMAS. 2013;7(2):97-104.

16. Dahlan S. Besar sampel dan cara pengambilan sampel dalam penelitian kedokteran dan kesehatan. Edisi 3. Jakarta: Salemba Medika; 2013. p. 68.

17. Aliyah DP, Septrianan, Prasetyaningrum YI. Status gizi , aktivitas fisik, dan asupan zat gizi makro antara siswa sekolah dasar full day dan half day. J Ilmu Gizi Indones. 2018;2(1):59-68.

18. Bujuri DA. Analisis perkembangan kognitif anak usia dasar dan implikasinya dalam kegiatan belajar mengajar. Literasi. 2018;9(1):37-50.

19. BPS. Tabel dinamis subjek kemiskinan dan ketimpangan. [Internet]. Jakarta: BPS; 2019 [cited 3 November 2019]. Available from: https://www.bps.go.id/subject/23/kemiskinandan-ketimpangan.html.

20. Kemenkes. Keputusan menteri kesehatan republik indonesia tentang standar antropometri status gizi anak. Jakarta: Direktorat Bina Gizi; 2011.

21. Rohayati, Zainafree I. Faktor yang berhubungan dengan penyelenggaraan program makan siang di sd al-muslim tambun. Unnes J Public Heal. 2014;3(3):1-9.

22. Kowalski K, Crocker P, Donen R. The physical activity questionnaire for older children (PAQC) and adolescents (PAQ-A) Manual. Canada: College of Kinesiology University of Saskatchewan; 2004.

23. Dahlan S. Statistik untuk kedokteran dan kesehatan. Edisi 6. Jakarta: Salmba Medika; 2014

24. Dongoran SN, Siagian A, Lubis Z. Kecukupan energi dan protein serta status gizi siswi SMP yang mendapat makan siang dan tidak mendapat makan siang dari sekolah dengan sistem fullday school. Gizi, Kesehat Reproduksi dan Epidemiol. 2016;1(5).

25. Hardiansyah S. Ilmu Gizi Teori dan Aplikasi. Jakarta: EGC; 2017.

26. Kurniawati P, Fayasari A, Kecamatan P, Minggu P. Sarapan dan asupan selingan terhadap status obesitas pada anak usia 9-12 tahun breakfast and snacking intake on obesity status in children 
aged 9-12 years old. 2018;01(02):69-76.

27. Miyaki $T$, Imada $T$, Hao SS, Kimura E. Monosodium L -glutamate in soup reduces subsequent energy intake from high-fat savoury food in overweight and obese women. Br J Nutr. 2016;115:176-84.

28. Sediaoetama A. Ilmu gizi untuk mahasiswa dan profesi. Jakarta: Dian Rakyat; 2010.

29. Hammond K, Mahan L. Intake: Analysis of the diet. In: Krause's Food and The Nutrition Care Process. 14th ed. Missouri: Elsevier Inc. St Louis; 2017. p. 53.

30. Welis W, Rifki M. Gizi untuk aktifitas fisik dan kebugaran. Padang: Sukabina Press; 2013.

31. Romar JE, Enqvist I, Kulmala J, Kallio J, Tammelin T. Physical activity and sedentary behaviour during outdoor learning and traditional indoor school days among Finnish primary school students. J Adventure Educ Outdoor Learn. 2019; 19:(1):28-42.
32. Putra K, Kinasih A, Kriswandaru P. Gambaran aktivitas fisik siswa kelas IV sekolah dasar negeri di Salatiga. Semin Nas Pendidik Jasm UMMI Ke-1 Tahun 2018. 2018;244-8.

33. Nurhidayati V, Martianto D, Sinaga T. Energi dan zat gizi dalam penyelenggaraan makanan di taman kanak-kanak dan perbandingannya terhadap subjek tanpa penyelenggaraan makanan. J Gizi Pangan. 2017;12(1):69-78.

34. Lysen L, Israel D. Nutrition in Weight Management. In: Krause's Food and The Nutrition Care Process. 14th ed. Missouri: Elsevier Inc. St Louis; 2017. p. 392.

35. Adriani M, B W. Pengantar Gizi Masyarakat. Jakarta: Kencana Prenada Media Group; 2012. p. 264.

36. Anzarkusuma I, Mulyani E, Jus'at I, Angkasa D. Status gizi berdasarkan pola makan anak sekolah dasar di kecamatan rajeg tangerang. Indones $\mathbf{J}$ Hum Nutr. 2014;1(2):135-48. 